\title{
Lumen
}

Selected Proceedings from the Canadian Society for Eighteenth-Century Studies

\section{Sarah Trimmer's Oeconomy of Charity: Politics and Morality in the Sunday School State}

\section{Deborah Wills}

Volume 12, 1993

URI : https://id.erudit.org/iderudit/1012588ar

DOI : https://doi.org/10.7202/1012588ar

Aller au sommaire du numéro

Éditeur(s)

Canadian Society for Eighteenth-Century Studies / Société canadienne d'étude du dix-huitième siècle

ISSN

1209-3696 (imprimé)

1927-8284 (numérique)

Découvrir la revue

Citer cet article

Wills, D. (1993). Sarah Trimmer's Oeconomy of Charity: Politics and Morality in the Sunday School State. Lumen, 12, 157-166. https://doi.org/10.7202/1012588ar

Copyright (c) Canadian Society for Eighteenth-Century Studies / Sociéte canadienne d'étude du dix-huitième siècle, 1993
Ce document est protégé par la loi sur le droit d'auteur. L'utilisation des services d'Érudit (y compris la reproduction) est assujettie à sa politique d'utilisation que vous pouvez consulter en ligne.

https://apropos.erudit.org/fr/usagers/politique-dutilisation/ 


\section{Sarah Trimmer's OEconomy of Charity: Politics and Morality in the Sunday School State}

The final quarter of the eighteenth century saw a rapid and widespread increase in the establishment of rural English Sunday Schools by philanthropists from both the upper and professional classes; by 1799, two hundred thousand pupils were accommodated annually, a figure that swelled to over two million in the subsequent fifty years. As the number of institutions and pupils increased, however, so did the vehemence of opposition to the Sunday School movement. Both protest and support were accelerated by changing social constructions of childhood: paradoxically, as a newly sentimental and romanticized view of childhood emerged, so did a more pragmatic sense of the child as a crucial national resource. Children were considered to belong, as articulated by the Reverend David Turner, 'less to their parents than to the public'; they were seen as 'the hope and strength of the body politic' (qtd. in Laqueur 125). The instability and frangibility of this political body, however, localized in the perceived collapse of 'natural' laws of subordination, placed the child ever more centrally as both locus and agent of social change. Fear of the imminent disintegration of England's social fibre suggested the need for an instrument of moral rescue that would regenerate both children as individuals and, through them, society as a whole. While advocates claimed that Sunday Schools provided this instrument, detractors warned that these charities actually engendered and fostered the very anarchic forces they were attempting to stem. Attacked as vigorously in Parliament as in the pulpit, Sunday Schools were considered promulgators of social disorder. Sunday School founder and apologist Sarah Trimmer (1741-1810) undertook to quell this controversy with her 1787 treatise, The CEconomy of Charity: or, An Address to Ladies concerning Sunday Schools; the Establishment of Schools of Industry under Female Inspection; and the distribution of Voluntary Benefactions, a text Trimmer directs primarily to women 'in the middling stations of life' (3). While ostensibly remaining respectably within the province of the 'distaff and needle' (85), Trimmer's CEconomy is actually informed by a highly politicized subtext which anticipates, subverts, and counters anti-Sunday 
School arguments. She outlines a programme through which the Sunday School, when properly administered, can serve as a means of instituting social control and intensifying hierarchy. Through her schedule of carefully organized mutual exposure between the middle and lower classes, difference is not dissolved but consolidated. Trimmer's carefully modest and unassuming text is thus revealed as a middle-class manifesto for the appropriation of social, political, and religious power in the name of moral instruction.

Trimmer's treatise is overtly devoted to discussions of curriculum, schedules, rules and uniforms, and to defending Sunday Schools in general from the common charges of being dirty, noisome, and germladen. Sub-textual interpellations, however, are subtly engineered towards answering more serious allegations against the Schools. Far from furthering social, political, and religious insurrection, Trimmer suggests, Sunday Schools offer instead a regulatory and juridical means of institutionalizing social, political, and religious control. Those opposing Sunday Schools out of a fear of religious disruption drew ominous parallels to the levelling tendencies associated with the heterodoxies of Dissent. High Church distrust of the ever-growing number of itinerant preachers was linked to charitable instruction in George Hadley's assertion that 'these pernicious vagrants will be increased when ALL CAN READ, and when all claim the right of putting their own construction on what they can read' (qtd.in Laqueur 125). The usurpation of the spiritual mysteries by thelaity offended the Church of England's sense of religious order; social order was also seen to be imperilled. The Gentleman's Magazine, originally supportive of the Sunday Schools founded by Robert Raikes in the early 1780s, published in 1797 an attack on these same organizations as 'subversive of that order, that industry, that peace and tranquillity which constitute the happiness of society; and ... so far from deserving encouragement and applause [they] merit our contempt, and ought to be exploded as the vain chimerical institution of a visionary' (qtd. in Merrill 5). This 'chimerical' nature of the Sunday Schools was itself illusory; it was, in fact, the very solidity with which various Sunday School programmes were being entrenched that generated much of their detractor's alarm. A similar distrust is evidenced in the Orthodox Churchman's Magazine's portrayal of a Sunday School's sinister metamorphosis:

A school room was erected-children admitted-and a mistress was appointed; but alas! Short-lived was this delusive scene: The matron's armchair gradually grew into a pulpit- - the children's benches were metamorphosed into Pewsand the School-room became a Meeting-house. Such practises merit exposure, and cannot fail to open the eyes of the world. (qtd. in Laqueur 129) 
While Trimmer's text avoids directly confronting accusations of this nature, the cool and measured rhetoric of The CFconomy of Charity seems in itself a refutation of the emotionally-charged tone adopted by these denunciations: the Churchman's typography is laden with the italics, dashes, and exclamation marks that are comparatively absent in Trimmer's treatise. The Churchman's terror of a woman behind the pulpit is skilfully assuaged by Trimmer's self-deprecatory narrative voice, with its reiterated promises of an imminent 'return to the distaff and needle' (81). Further, Trimmer makes clear that her educational mandate is based not on personal ambition but upon 'maternal instinct' (20) and is therefore, she claims, 'perfectly consistent with the female character' (4). By focusing on the naturalness of the nurturing woman, she deflects attention away from the unnaturalness of a woman sharing para-ecclesiastical influence. More significantly, however, Trimmer illustrates that, rather than encouraging a diminution of ecumenical authority, a well-administered Sunday School actually protects and extends that authority by establishing control over the sacred texts. She demonstrates that the person who teaches a child to read the Bible is the one who teaches her how to read the Bible, how to construe sentences not just grammatically but politically. Instruction, as Trimmer implies, is always a value-laden procedure; therefore in competent (read middle-class) hands, it resists, rather than fosters, anarchy and liberalism.

Language itself, as an instructional tool, is equally value-laden. Cognizant of the linguistic gap between the classes, Trimmer provides a common language made up of a religious vocabulary. While ostensibly reaching across class lines, however, this religious language is actually predicated upon class differentiation. 'The high and middling ranks are so refined,' she reflects, 'and the lower so vulgar, that their language is in many cases as unintelligible to each other as if they came from different regions of the world' (11). Trimmer proposes to rectify this difference by initiating the poor into a shared theological lexicon that defines all its terms in a manner convenient to the author and to the interests of her class. The ratio of biblical text to exposition and analysis in Trimmer's multi-volumed Sacred History reflects this. Sacred History is a selection of expurgated and 'suitable' passages from the Old and New Testaments, in which every scriptural word has its equivalent not just in explanation and expostulation, but, more importantly, in definition. Trimmer's hermeneutic provides a meta-commentary so extensive that it overwhelms, by sheer bulk, the text upon which it is enlarging, and her glosses upon such biblical concepts as 'duty' generally translate into concrete and class-distinct instructions. From the story of Abraham, Sarah, and Hagar, for example, Trimmer derives the moral that 'it is the duty of servants to submit to their mistresses, even if the latter carry their 
displeasure to an unreasonable height' (94). As Trimmer's Introduction states, she wrote Sacred History to avoid the unspecified and mysterious 'inconveniencies' that might 'attend [children's] indiscriminate use of the Scriptures' (viii) or, worse, the reading of the Bible 'in a promiscuous manner' (vii). These 'inconveniencies' doubtless reside in the unsupervised readers' tendency to, in George Hadley's words, 'put their own construction' on what they read. In Trimmer's own Sunday School at her home in Old Brentford, Bible reading was anything but promiscuous, occurring only under the rigorous superintendence of a monitor who acted as translator; for, as Trimmer reiterates, the Bible is itself 'in many respects like a foreign tongue' (145), a tongue safely interpreted only by middle-class instructors.

Control of religious language leads, as Trimmer demonstrates, directly to social control. Anti-Sunday-School sentiment originating in the fear of anarchy suggested that education would topple the social hierarchy by making the poor contemptuous and familiar. As deeply rooted, however, was the fear that education would make the poor a less useful property by disinclining them to their rightful labours. Not only would education 'teach them to read seditious pamphlets, books and publications against Christianity,' warned the Hon. John Byng, but it would render them unfit for 'the laborious employment to which their rank in society had destined them' (qtd. in Carpenter 102). Trimmer shares this concern for social station, since 'in appointing different ranks among mankind, our all-wise Creator undoubtedly intended the good of the whole' (3). The evidence of the CEconomy demonstrates, however, that far from disrupting social roles, as Byng, Hadley, the Archbishop of Canterbury and others argued, Trimmer's educational programme reinforces them. She asserts, for example, that it is appropriate for young middle-class girls to assist in the Sunday Schools, not merely for their moral edification, but because

it is chiefly for them that we are endeavouring to train up to religion and virtue, servants, labourers, and mechanics: the rising generation of poor are instructed by us, that our children may be served better than their parents have been. (26)

Trimmer seems eager to re-establish a system in which the loyalty of the servant is due to both the concept 'master' in the abstract and the individual master in the flesh. When she laments that servants are no longer 'attached' (26) to their masters or to their 'native places' (102), then, Trimmer appears to be suggesting both an affectionate and a physical/geographical bond. Instead of familiarity breeding contempt, personal ties of respectful affection are being generated in the Sunday 
scholars for the young ladies destined to become their mistresses, while the idea of loyalty to any potential idealized 'mistress' is simultaneously inculcated.

Trimmer proposes other causes, besides lack of 'attachment,' for the general want of social 'unanimity' (4): when the poor are uninstructed and 'excluded from good example,' they fall into 'habits of vice and profaneness' which further distance them from their superiors, who then find contact 'degrading and unbecoming, if not dangerous' (12). The lower orders, angry at being 'kept at this mortifying distance,' then develop further 'unfavourable prejudices' against 'those whom Providence has placed above them' (13). Trimmer proposes to replace this cycle of alienation with a cycle of emulation: by juxtaposing the poor and the comparatively wealthy within the controlled environment of the Sunday School, she establishes a chain of imitation and attachment through which social concord is restored. This harmony is predicated, however, upon the maintenance of a certain minimum distance between the classes; Trimmer recognizes that proximity can be used to solidify, as well as to dissolve, difference. Exposing well-bred young ladies to 'a set of low-bred children' (41) thus brings about a two-fold result: the manners of the poor children are, through good example, improved (even if only, she concedes, to the extent of 'preventing their being disgusting' [41]), while the contrast between the two groups will still 'be so striking' that it will have a similarly salutary effect upon the young ladies, exciting them 'to pay a nicer attention to those graces which distinguish well-bred people' (41, my emphasis). Trimmer's emphasis on the benefits of middle- and lower-class interaction was unique. Raikes, for example, whose work was contemporary to Trimmer's, paid 'some poor woman a shilling a day to teach.' Despite his lack of Trimmer's middle-class models, he proposed an 'experiment' as to whether, 'when disciplined and instructed,' lower-class children 'would show the same evidences of human feelings and instincts as those more favorably situated' (qtd. in Merrill 3). Trimmer's focus, however, despite similar concerns for 'civilized' dress, manners, and appearance, remains on class interaction. Such exposure will, she claims, 'not refine [the poor children] to such a degree as to place them on a level with the young ladies who have a regard to real refinement' (41), but will make them more docile and presentable. Mutual influence thus becomes (as, for Trimmer, it always is) a matter of degree.

Even this pattern of class emulation, however, must fall within carefully delimited parameters. Concerned not just with the inculcation of virtue, but with the inculcation of socially appropriate virtues, Trimmer ensures that the models provided in the Sunday Schools are representative of these virtues, as exemplified by the middle class. To this end, 
she deliberately relegates the aristocracy to a passive role; they may donate funds and grace subscription lists, but they are to be spared any more rigorous involvement. Trimmer's tone, addressing upper class readers, is on the surface humble and self-effacing; she 'begs their indulgence' at the outset of her text, for appearing to 'dictate' to 'ladies of rank and fortune' (2). However, immediately after addressing these 'ladies of rank,' Trimmer reveals that it is 'persons in the middling stations of life' to whom she is 'particularly' addressing her work (3). Having just assured her readers that it is perfectly safe and healthy for the daughters of the middle class to visit Sunday Schools, for example, she adds that there is 'no need for British ladies to hazard their lives'; they may be 'patriots upon easier terms' (125). Trimmer's shifting of charitable responsibility away from the upper classes and towards the middle is in marked contrast to much of contemporary philanthropic thought. Even Hannah More, who was much inspired by Trimmer's work, turned in her own writings to the aristocratic model of charity. More's representations of charity as the prerogative, as well as the duty, of the upper-class woman solidified a social model that was to establish the parameters of genteel philanthropy into the nineteenth century (Johnson 101). In Colebs in Search of a Wife, More writes that 'Charity is the calling of a lady,' and that 'the care of the poor is her profession' (226). Trimmer, however, cognizant of the political and social power inhering in the control of charitable instruction, is reluctant to let that control pass out of middle-class hands. By barring the aristocracy from active participation, Trimmer ensures that those who actually regulate the Sunday School curriculum are those who will both embody and perpetuate bourgeois virtues.

While instructing her charges on the nature of the biblical 'inheritance that fadeth not away' (126), Trimmer is careful never to underestimate the value of the lower orders as a national inheritance in themselves. 'In forming an idea of the prosperity of a Nation,' she writes,

we must not estimate by the extent of territory, the number of people, or the quantity of gold and silver, but by the proportion of its members who live agreeable to that RIGHTEOUSNESS which can alone exalt a Kingdom. (v,vi)

While many of her contemporaries were uncertain as to how to refine this raw resource in the most profitable way, Trimmer's answer lay in her inculcation of nationalism, specifically of a nationalism dependant upon the perpetuation of class division (that 'subordination of ranks, which is requisite in all civilized societies' [60]), and upon the replace- 
ment of the upper class with the middle class as the model for emulation. In her discussion of the ordering of her own Sunday School, Trimmer refers to two specific texts used as primers for instruction and memorization: the Old Testament Psalms, and the Divine Songs of Isaac Watts. This choice of materials is significant: both the Psalms and the Divine Songs manifest exactly the kind of nationalism that Trimmer is so anxious to instill.

The Psalms deal with the children of Israel as a 'peculiar people,' a nation set apart and, by virtue of God's calling, distinct from all other nations. With considerable skill, Trimmer transfers to the English this sense of a national identity circumscribed by God's calling, of being a Chosen People. She achieves this, in part, by substituting orthodox Christian practises for traditional Hebraic rituals of initiation and identification: 'the rite of circumcision is now abolished,' she writes in her Sacred History,

but we have baptism in its stead, which is the token and pledge of a covenant conveying better promises. If it was necessary for Abraham and his family, and their descendants, to comply with the first, it must be our indispensable duty to comply with the latter.... Can children too early in life be numbered amongst God's peculiar people ... ? (99; my emphasis)

Trimmer also devotes particular attention to biblical prophecies in her commentary, explaining that 'they alone unfold the councils of Divine wisdom in respect to Nations'; she discusses these prophecies and their subsequent 'national judgements' as if they apply equally to the historical Jewish and the contemporary English nations. Her use of similarly nationalistic language in explicating both Biblical and contemporary culture further cements her identification of the British with the Chosen People.

Isaac Watts' Divine Songs echo this confidence in England as set apart by God; while Watts too draws a connection between the British and the Jewish nations, it is in order to exalt the spiritual superiority of the former over the latter:

Lord, I ascribe it to thy Grace, And not to Chance, as others do That I was born of Christian Race, And not a Heathen, or a Jew. (9) 
This spiritual hegemony suggests a divinely-ordained national identity: like race and religion, nationality becomes an index of heavenly favour. Moreover, the heathens, Jews, and other non-English have obviously merited their inferior position in the geographical as in the universal hierarchy, since these orderings are ascribable 'not to Chance' but to celestial intervention. Watts' brand of nationalism becomes cyclical and self-perpetuating: the Sunday scholar is instructed to rejoice, with the Songs' narrator, that he 'was taught, and learnt so young/ To read his holy Word' (11), while recognizing that this education depends on his being 'born on Brittish Ground' (8), which teaches him in turn that he must 'not change [his] native Land/ For rich Peru with all her Gold' (8). Trimmer's programme prevents any interrogation of that identity; she specifies that children should receive only as much education as 'shall enable them to read the Scriptures,' and know both 'the plain duties of Christianity' and 'those modes of conduct which their station requires' (37). Trimmer specifically mentions, for example, that she does not intend 'that the children of the poor should be instructed in languages, geography, history, and other articles that constitute a polite education' (37). She thus limits their identity as a class to a social/religious construct, excluding from it the historical, geographical, and linguistic elements that could, by enabling her scholars to place themselves in a broader, extra-cultural context, lead them to question the 'ordained' nature of their present roles.

Trimmer's programme thus becomes a self-perpetuating system of social control through the institutionalization of class divisions and social ordering. Occasionally the extent of this control was manifest in ways more tangible than was usual to Trimmer's project. The section of the CEconomy devoted to 'the distribution of Voluntary Benefactions,' for example, proposes a system of lessening, if not abolishing, the obligatory poor rates, and relying instead on 'spontaneous casual charity' (121). The spontaneity of the charitable enterprise is called into question, however, as Trimmer demonstrates the ways in which such a scheme could be exploited. Her 'Address to Parents' warns 'persons as refuse these offers of instruction for their children' that 'they can not expect the notice of their superiors, nor relief by private charity,' while those who cooperate will 'receive every proper encouragement' (178). In her Fabulous Histories, Trimmer illustrates the same principles for the young: the baby bird who tries to usurp nest-space is made to sit outside the nest and denied his dinner 'whilst,' Mama Robin tells him, 'I cherish those who are dutiful and good' (26). These admonitions are echoed in the final words of the CFconomy, where Trimmer concludes that, as her system ensures, 'Wickedness is certain of being punished in the next life; but, even in this world, it generally meets with discouragement' (182). 
The discouraging practices aimed at suppressing the Sunday School movement, ranging from Parliamentary denunciation to pelting the participants with 'filth of all descriptions and dirty water,' gradually died out in the face of the movement's unabating popularity. The institutions that were originally condemned as 'striking a blow at the very vitals of the Establishment,' as one clergyman complained to a member of the Edinburgh Gratis Sabbath School Society, were eventually embraced by the establishment (qtd. in Trumbull 9). By 1859, the Reverend James George was able to claim that although 'the time ... has not long gone past, when many persons of undoubted piety were unfriendly to [them],' there are 'few men of piety, at the present day, who will oppose Sabbath Schools,' now 'one of the grand institutions of our times' (101). Trimmer's skill and acuteness as an apologist for the Sunday Schools confirms her as an important factor in their eventual acceptance. Her adversaries prophesied that, if Sunday Schools continued, 'the legislature would find it necessary to [employ] the strong arm of power' (qtd. in Laqueur 126). Trimmer revealed, however, that a much stronger force than the government's 'strong arm' could be brought to bear on the lower classes through the patterns of emulation and inculcation established in the Sunday Schools. A pliant, dutiful, and industrious lower class thus becomes, for the middle class, the immediate and earthly reward corresponding to the distant and heavenly prize anticipated by the poor; it is this terrestrial incarnation of the celestial inheritance that becomes the basis for Trimmer's 'true œconomy of charity' (126).

\section{DEBORAH WILLS}

University of Alberta

\section{Works Cited}

Carpenter, S.C. Eighteenth-Century Church and People. London: John Murray, 1959.

The Development of the Sunday-School 1780-1905: The Official Report of the 11th International Sunday-School Convention. Boston: Executive Committee of the International Sunday-School Association, 1905.

George, Rev. James, D.D. The Sabbath School of the Fireside: and the Sabbath School of the Congregation As It Ought To Be. Kingston: John Creighton, 1859.

Johnson, Dale A. Women in English Religion 1700-1925. New York: Edwin Mellen, 1983.

Laqueur, Thomas Walter. Religion and Respectability: Sunday Schools and Working Class Culture 1780-1850. New Haven: Yale UP, 1976. 
Merrill, George R., D.D. 'Robert Raikes and the Eighteenth Century.' Development 1-6.

More, Hannah. Colebs in Search of a Wife. 1809. New York, n.p., 1857.

Trimmer, Sarah. Fabulous Histories, Designed for the Amusement and Instruction of Young Persons. Philadelphia: Gibbons, 1794.

-. The CEconomy of Charity; or, An Address to Ladies concerning Sunday-Schools; the Establishment of Schools of Industry under Female Inspection; and the distribution of Voluntary Benefactions. London: T. Longman, 1787.

-. Sacred History Selected From the Scriptures; with Annotations and Reflections, particularly calculated to facilitate the study of the Holy Scriptures in Schools and Families. 5th ed. London: J. Johnson, 1806.

Trumbull, Charles Gallaudet. 'The Nineteenth-Century Sunday-School.' Development 718.

Watts, Isaac. Divine Songs. Classics of Children's Literature 1621-1932. Ed. Alison Lurie and Justin G. Schiller. New York: Garland, 1978. 